\title{
The effects of irrigation methods on some of soil and plant microbial indices using treated municipal wastewater
}

\author{
Payam Najafi $\cdot$ Jahangir Shams $\cdot$ Azita Shams
}

Received: 3 November 2014/ Accepted: 3 February 2015/Published online: 18 February 2015

(C) The Author(s) 2015. This article is published with open access at Springerlink.com

\begin{abstract}
Shortage of irrigation water is a crucial problem in arid and semi-arid regions. Therefore, application of wastewater in such area seems to be an indispensable solution. The health aspect of the application should be considered by microbial evaluation of soil and plant irrigated with treated wastewater. In this study several irrigation methods were used. Results showed that the filtration reduced the microbial pollution of treated municipal wastewater. The maximum soil pollution was in the surface drip and furrow irrigation with treated municipal wastewater. The least level of total and fecal coliform were in sub-surface drip irrigation at the depth of $30 \mathrm{~cm}$ in condition of municipal wastewater reuse. The results of plants revealed that the highest coliforms were seen at the surface drip and furrow irrigation with treated municipal wastewater. The minimum coliforms numbers were observed in the sub-surface drip irrigation method. Therefore, the sub-surface drip irrigation can reduce the wastewater reuse problems at soil and plant. It is the best option to avoid the contamination in landscape.
\end{abstract}

Keywords Irrigation method - Microbial contamination · Municipal wastewater $\cdot$ Landscape

P. Najafi

Department of Water Engineering, Agricultural Faculty, Isfahan (Khorasgan) Branch, Islamic Azad University, Isfahan, Iran e-mail: payam.najafi@gmail.com

J. Shams $(\varangle) \cdot$ A. Shams

Young Researchers Club, Isfahan (Khorasgan) Branch, Islamic Azad University, Isfahan, Iran

e-mail: shams.jahangir@yahoo.com

A. Shams

e-mail: shamsazita96@yahoo.com

\section{Introduction}

Nowadays, due to water scarcity it is very common to use the treated wastewater in agriculture. Risk analysis is an integrated framework for wastewater reclamation and reuse consisting of risk assessment and management (Ganoulis 2012). The reuse of treated effluent can decrease impacts of pig manure on the environment and water resources (Velho et al. 2012). Evaluation of soil quality and environmental observation are very important for the wastewater irrigation. Kalavrouziotis et al. (2008) reported that treated municipal effluent increased the concentrations of heavy metals and fecal coliform levels in the edible portion of the cabbages. The attentions of chemical constituents in soil layers were influenced by the water movement and chemical concentrations in irrigation water (Heidarpour et al. 2007). The most important concern with the sub-surface irrigation was the increased effluence in the top soil layer, since it might inhibit plant growth (Tabatabaei and Najafi 2009).

\section{Methods}

The experiment was performed at research center in Isfahan municipal wastewater treatment plant in 2008. The Table 1 presents the chemical analysis of fresh water and treated municipal wastewater (TMW). Soil texture was loam, EC (6.6 ds/m) and SAR (6.1).

Four biological parameters including the numbers of total coliform (TC), fecal coliform (FC), total plate count (TPC) and parasite zygote were measured in effluent of wastewater treaded plant after filtration. Laurus nobilis and Buxus sempervirens plants were cultivated in the plots with three replications. Experimental treatments included, T1 
Table 1 Chemical analysis of the fresh water and treated municipal wastewater

\begin{tabular}{|c|c|c|c|c|c|c|c|c|c|c|c|c|}
\hline Irrigation & $\begin{array}{l}\text { EC } \\
(\mathrm{ds} / \mathrm{m})\end{array}$ & $\mathrm{pH}$ & $\mathrm{SAR}_{\mathrm{iw}}$ & $\mathrm{SAR}_{\mathrm{adj}}$ & $\begin{array}{l}\text { BOD } \\
(\mathrm{mg} / \mathrm{l})\end{array}$ & $\begin{array}{l}\text { COD } \\
(\mathrm{mg} / \mathrm{l})\end{array}$ & $\begin{array}{l}\mathrm{Na} \\
(\mathrm{meq} / \mathrm{l})\end{array}$ & $\begin{array}{l}\mathrm{NO}_{3} \\
(\mathrm{mg} / \mathrm{l})\end{array}$ & $\begin{array}{l}\mathrm{NH}_{4} \\
(\mathrm{mg} / \mathrm{l})\end{array}$ & $\begin{array}{l}\mathrm{SO}_{4} \\
(\mathrm{meq} / \mathrm{l})\end{array}$ & $\begin{array}{l}\mathrm{HCO}_{3} \\
(\mathrm{meq} / \mathrm{l})\end{array}$ & $\begin{array}{l}\mathrm{Mg} \\
(\mathrm{meq} / \mathrm{l})\end{array}$ \\
\hline Fresh water & 0.5 & 7.4 & 1 & 1.8 & - & - & 1.4 & 0.5 & - & 1.6 & 2 & 1.2 \\
\hline $\begin{array}{l}\text { Treated municipal } \\
\text { wastewater }\end{array}$ & 1.4 & 7.5 & 3.3 & 8 & 34.4 & 85.3 & 6.3 & 1.28 & 29.2 & 2.2 & 6.8 & 2.4 \\
\hline
\end{tabular}

Table 2 Level of microbial parameters of treated municipal wastewater

\begin{tabular}{llll}
\hline Parameter & Before filtration & After filtration & Removal efficiency (\%) \\
\hline Total plate count (N/ml) & $8.6 \times 10^{6}$ & $9.3 \times 10^{4}$ & 98.9 \\
Total coliform (MPN/100 ml) & $9.3 \times 10^{7}$ & $4.3 \times 10^{3}$ & 99.0 \\
Fecal coliform (MPN/100 ml) & $4.3 \times 10^{7}$ & $2.3 \times 10^{3}$ & 99.0 \\
Parasite zygote (N/L) & 3.5 & 1.5 & 57.1 \\
\hline
\end{tabular}

Table 3 Means of coliforms levels in 1 gr soil

\begin{tabular}{|c|c|c|c|c|c|c|c|}
\hline \multicolumn{4}{|c|}{ Total coliform } & \multicolumn{4}{|c|}{ Fecal coliform } \\
\hline Treatment & First sampling & Secondary sampling & Average & Treatment & First sampling & Secondary sampling & Average \\
\hline $\mathrm{T} 1^{\mathrm{c}}$ & $9 \times 10^{3}$ & $5 \times 10^{6}$ & $2 \times 10^{6}$ & $\mathrm{~T} 1^{\mathrm{d}}$ & $1.5 \times 10^{3}$ & $4.3 \times 10^{3}$ & $2.9 \times 10^{3}$ \\
\hline $\mathrm{T} 2^{\mathrm{b}}$ & $2 \times 10^{9}$ & $4 \times 10^{7}$ & $6 \times 10^{8}$ & $\mathrm{~T} 2^{\mathrm{a}}$ & $3 \times 10^{9}$ & $7 \times 10^{5}$ & $1.5 \times 10^{8}$ \\
\hline $\mathrm{T}^{\mathrm{c}}$ & $3 \times 10^{6}$ & $1 \times 10^{6}$ & $2 \times 10^{6}$ & $\mathrm{~T} 3^{\mathrm{b}}$ & $2 \times 10^{6}$ & $2 \times 10^{4}$ & $1 \times 10^{6}$ \\
\hline $\mathrm{T} 4^{\mathrm{c}}$ & $2 \times 10^{6}$ & $5 \times 10^{6}$ & $2 \times 10^{4}$ & $\mathrm{~T} 4^{\mathrm{c}}$ & $9.3 \times 10^{4}$ & $2 \times 10^{4}$ & $6 \times 10^{4}$ \\
\hline $\mathrm{T} 5^{\mathrm{a}}$ & $5 \times 10^{10}$ & $9 \times 10^{6}$ & $2 \times 10^{10}$ & $\mathrm{~T} 5^{\mathrm{a}}$ & $7.5 \times 10^{7}$ & $2.1 \times 10^{5}$ & $4 \times 10^{7}$ \\
\hline
\end{tabular}

The mean for each experimental factor in each characteristic which has at least one letter in common are not statistically significant based on Duncan test at $5 \%$ level

furrow irrigation with fresh water, T2 the surface drip irrigation (DI) with treated municipal wastewater, T3 the sub-surface drip irrigation (SDI) at the depth of $15 \mathrm{~cm}$ with TMW, T4 the SDI at the depth of $30 \mathrm{~cm}$ with TMW, T5 the furrow irrigation with TMW. The system outflow was regulated for a $2.5 \mathrm{~m}^{3} / \mathrm{h} / \mathrm{m}^{2}$. The diameter of secondary pipe was $16 \mathrm{~mm}$, the dripper distance was $30 \mathrm{~cm}$, and the rate of drippers was $2.5 \mathrm{l} / \mathrm{h}$. After irrigation, the samples were taken during of studies and then their TC and FC in soil and plant shoots were measured at three stages by MPN method.

\section{Result and discussion}

According to the results, biological parameters decreased by filtration of the wastewater effluent. Reduction of TPC, TC and FC parameters showed up to $99 \%$ and level of parasite zygote up to $57 \%$ after filtration (Table 2).

The highest levels of coliforms were related to the DI and furrow irrigation with treated municipal wastewater. There are no significant differences between the other treatments in total coliform. The minimum level of fecal
Table 4 Comparison of the coliforms levels at plants shoots

\begin{tabular}{llllll}
\hline Treatment & Laurus & & & \multicolumn{2}{l}{ Buxus } \\
\cline { 2 - 3 } & TC & FC & & TC & FC \\
\hline T1 & ns & ns & 3 & ns \\
T2 & 35 & ns & 41 & ns \\
T3 & 7 & ns & 2 & ns \\
T4 & 6 & ns & 1 & ns \\
T5 & 28 & ns & 41 & 35 \\
\hline
\end{tabular}

The mean for each experimental factor in each characteristic which has at least one letter in common are not statistically significant based on Duncan test at $5 \%$ level, $n s$ not seen

coliform belonged to the $\mathrm{T} 1, \mathrm{~T} 4$ and $\mathrm{T} 3$, respectively (Table 3).

It could be concluded that the use of SDI method, in comparison with furrow and DI, decreases the surface soil pollution. Of course in this condition, the pollution of wastewater relative to fresh water irrigation should have no significant difference. Results of Laurus nobilis shoots showed that, total coliform was not seen at furrow irrigation with fresh water treatment. The lowest level of TC 
was obtained in the sub-surface drip irrigation system with TMW at the depth of 30 and $15 \mathrm{~cm}$, respectively. The maximum level was seen in the DI (35 MPN/100 ml) and furrow irrigation $(28 \mathrm{MPN} / 100 \mathrm{ml})$ with treated municipal wastewater. Also, there was no fecal coliform in Laurus. In shoots of Buxus sempervirens, the highest level of TC indicated at DI and furrow irrigation with TMW (41 MPN/100 ml). The minimum level of TC was shown in the T4, T3 and T1, respectively. Also the fecal coliform parameter was not found in all of treatments except the furrow irrigation with treated municipal wastewater (Table 4).

\section{Conclusion}

Soil pollution decreased with the increased depth of installed drippers, as could be observed from the sub surface drip technique. The study showed that the furrow and drip irrigations had the highest soil microbial pollution. The lowest level of microbial contamination of soil was seen in the sub surface drip irrigation using the treated municipal wastewater. The study also revealed that shoots of Buxus and Laurus had high microbial contaminations with surface drip and furrow irrigations.
Open Access This article is distributed under the terms of the Creative Commons Attribution License which permits any use, distribution, and reproduction in any medium, provided the original author(s) and the source are credited.

\section{References}

Ganoulis J (2012) Risk analysis of wastewater reuse in agriculture. Int J Recycl Organ Waste Agric 1:3

Heidarpour M, Mostafazadeh-Fard B, Koupai JA, Malekian R (2007) The effects of treated wastewater on soil chemical properties using subsurface and surface irrigation methods. Agric Water Manag 90:87-94

Kalavrouziotis IK, Robolas P, Koukoulakis PH, Papadopoulos AH (2008) Effects of municipal reclaimed wastewater on the macroand-micro-elements status of soil and of Brossica oleracea Var. Italica, and B. oleracea Var. Gemmifera. J Agric Water Manag 95:419-426

Tabatabaei SH, Najafi P (2009) Effects of irrigation with treated municipal wastewater on soil properties in arid and semi-arid regions. Irrig Drain J 58:551-560. doi:10.1002/ird.449

Velho VF, Mohedano RA, Filho PB, Costa RHR (2012) The viability of treated piggery wastewater for reuse in agricultural irrigation. Int J Recycl Organ Waste Agric 1:10 